\title{
MODEL PENGEMBANGAN KEGIATAN KEAGAMAAN PADA IKATAN REMAJA MASJID (IRMA) LUQMAN SMA NEGERI 10 BANDUNG
}

\author{
Nan Rahminawati \\ Fakultas Tarbiyah, Universitas Islam Bandung, Jl. Ranggagading No.8 Bandung \\ Email: nan_rahminawati@unisba.ac.id
}

DOI: $10.29313 /$ tjpi.v6i2.4629

Accepted: January 18th, 2018. Approved: January 28th, 2018. Published: January 28th, 2018

\begin{abstract}
Religious education is one of three compulsory subjects given to each type, path, and level of education. Implementation of religious education one of them conducted the Moslem Youth Association (IRMA) which was formed and located in the High School (SMA). IRMA plays a strategic role in conducting religious guidance because it is done in a peergroup. One of the State High School (SMA) State that set extracurricular in the field of spiritual development under the school mosque is SMA Negeri 10 Bandung. Implementation of activities carried out IRMA in SMA Negeri 10 interesting to investigate further so that it can be used as a model for the implementation of extra-curricular activities similar in other high schools. Based on the methods and techniques used in this study, the final result is obtained that: The model developed in the implementation of 11 (eleven) activities is grouped on the information processing model, social, and behavioral. Furthermore, the model of development of religious activities on IRMA Luqman SMA Negeri 10 Bandung can use Input, Process, Output.
\end{abstract}

Keywords: Mosque Youth Ties, extracurricular, religious activities.

\section{ABSTRAK}

Pendidikan agama merupakan salah satu dari tiga mata pelajaran wajib yang diberikan pada setiap jenis, jalur, dan jenjang pendidikan. Implementasi pendidikan agama salah satunya dilakukan Ikatan Remaja Masjid (IRMA) yang dibentuk dan berada di lingkungan Sekolah Menengah Atas (SMA). IRMA memegang peranan strategis dalam melakukan pembinaan keagamaan, karena dilakukan secara peer-group. Salah satu Sekolah Menengah Atas (SMA) Negeri yang menetapkan ekstra kurikulernya dalam bidang pembinaan keagamaan di bawah Masjid sekolah adalab SMA Negeri 10 Bandung. Pelaksanaan kegiatan yang dilakukan IRMA di SMA Negeri 10 menarik untuk diteliti lebih lanjut, sehingga dapat dijadikan model dalam pelaksanaan kegiatan ekstra kurikuler serupa di SMA lainnya. Berdasarkan metoda dan teknik yang digunakan dalam penelitian ini, diperoleh hasil akhir bahwa: Model yang dikembangkan pada pelaksanaan 11 (sebelas) kegiatan dikelompokean pada model processing information, social, dan behavioral. Selanjutnya, model pengembangan kegiatan kegamaan pada IRMA Luqman SMA Negeri 10 Bandung dapat menggunakan model Input, Proses, Output.

Kata Kunci : Ikatan Remaja Masjid, ekstra kurikuler, kegiatan keagamaan. 


\section{PENDAHULUAN}

Visi Pendidikan Nasional yang berbunyi: "Terwujudnya sistem pendidikan sebagai pranata sosial yang kuat dan berwibawa untuk memberdayakan semua warga negara Indonesia berkembang menjadi manusia yang berkualitas sehingga mampu dan proaktif dan menjawab tantangan zaman yang selalu berubah", dituangkan kedalam salah satu misinya yakni: meningkatkan kesiapan masukan dan kualitas proses pendidikan untuk mengoptimalkan pembentukan kepribadian yang bermoral, melahirkan salah satu strategi pembangunan pendidikan nasional yakni : Pelaksanaan pendidikan agama serta akhlak mulia.

Pendidikan agama merupakan salah satu dari tiga mata pelajaran wajib yang diberikan pada setiap jenis, jalur, dan jenjang pendidikan. Bila dikaitkan dengan tujuan pendidikan Islam, maka pendidikan agama mestilah mampu mengantarkan seorang peserta didik kepada terbinanya tiga aspek, seperti dikemukakan Haidar Putra Daulay (2004;38): "Pertama, aspek keimanan mencakup seluruh arkanul iman. Kedua, aspek ibadah, mencakup seluruh arkanul Islam. Ketiga, aspek akhlak, mencakup seluruh akhlakul karimah".

Operasionalisasi pendidikan agama Islam di Sekolah Menengah Atas (SMA), diatur oleh Menteri Agama dengan Menteri Pendidikan Nasional, dengan ketentuan pelaksanaannya diajarkan selama dua jam setiap minggunya. Ketentuan tersebut sangatlah berat bebannya, apalagi memenuhi misi pendidikan nasional yakni mengoptimalkan pembentukan kepribadian yang bermoral. Selain permasalahan tersebut di atas, muncul fenomena di masyarakat dengan banyaknya permasalahan praktik keagamaan yang tidak sesuai dengan syariat Islam serta bentuk kenakalan remaja yang menimbulkan keresahan di kalangan masyarakat, seperti: Geng Motor, aliran-aliran agama yang sesat (al-Qur'an Suci, Al-Qiyadah al Islamiyah,
Inkarus sunnah, tawuran antar pelajar, dsb. Mencermati permasalahan yang muncul, Ikatan Remaja Masjid (IRMA) yang dibentuk dan berada di lingkungan Sekolah Menengah Atas (SMA) memegang peranan strategis dalam melakukan pembinaan keagamaan, karena dilakukan secara peergroup.

Salah satu Sekolah Menengah Atas (SMA) Negeri yang menetapkan ekstra kurikulernya dalam bidang pembinaan keagamaan di bawah Masjid sekolah adalah SMA Negeri 10 Bandung. SMA Negeri 10 Bandung merupakan salah satu Sekolah Menengah Atas Negeri yang berlokasi di Bandung Timur jalan Cikutra Nomor 77. SMA Negeri 10 Bandung memiliki nuansa yang berlainan dibanding sekolah negeri lainnya, diantaranya memiliki masjid paling besar untuk tingkat sekolah di Jawa Barat.

Untuk memperoleh gambaran model pengembangan kegiatan keagamaan yang dilakukan oleh Ikatan Remaja Masjid (IRMA) Luqman SMA Negeri 10 Bandung, maka diturunkan dalam rumusan masalah: (1) Pendekatan apa yang digunakan dalam kegiatan keagamaan yang dilakukan IRMA Luqman SMA Negeri 10 Bandung ? (2) Materi apa saja yang diberikan dalam kegiatan keagamaan yang diselenggarakan IRMA Luqman SMA Negeri 10 Bandung? (3) Bagaimana langkah yang ditempuh dalam mengembangkan kegiatan keagamaan yang diselenggarakan IRMA Luqman SMA Negeri 10 Bandung ? (4) Metoda apa saja yang digunakan untuk melaksanakan kegiatan keagamaan pada IRMA Luqman SMA Negeri 10 Bandung ? (5) Bagaimana model yang dikembangkan dalam pembinaan keagamaan oleh IRMA Luqman SMA Negeri 10 Bandung ? Penelitian ini menggunakan metode deskriptif analitik dengan pendekatan fenomenologi. Alasan pemilihan metode ini dikarenakan masalah yang dikaji menyangkut masalah yang sedang berkembang dalam kehidupan, khususnya terkait kegiatan keagamaan di lingkungan masjid sekolah SMA Negeri 10 Bandung serta aktivitas para pengurus 
IRMA SMA Negeri 10 Bandung dalam melaksanaan kegiatan pembinaan keagamaan. Adapun Teknik yang digunakan dalam penelitian ini adalah: wawancara, observasi, dan studi dokumentasi. Pelaksanaan analisis data dilakukan secara induktif.

\section{LANDASAN TEORI}

Teori yang dijadikan alat untuk menganalisis temuan data lapangan, terdiri atas: (1) Pembinaan Kegiatan Keagamaan. (2) Pengembangan Kegiatan Keagamaan Siswa di SMA. (3) Model-model Pembinaan Keagamaan

Proses pembinaan keagaamaan merupakan salah satu bagian dari proses pendidikan Islam. Dalam Kurikulum PAI (2002:3): "Pendidikan agama Islam merupakan usaba sadar dan terencana dalam menyiapkan peserta didik untuk mengenal, memahami, menghayati, hingga mengimani ajaran agama Islam”. Munculnya anggapan-anggapan yang kurang menyenangkan tentang pendidikan agama, seperti: Islam diajarkan lebih pada hafalan (padahal Islam penuh dengan nilainilai) yang harus dipraktika. Pendidikan agama lebih ditekankan pada hubungan formalitas antara hamba dengan TuhanNya; penghayatan nilai-nilai agama kurang mendapat penekanan dan masih sederet respons kritik terhadap pendidikan agama. $\mathrm{Hal}$ ini disebabkan penilaian kelulusan siswa dalam pelajaran agama diukur dengan berapa banyak hafalan dan mengerjakan ujian tertulis di kelas yang dapat didemontrasikan oleh siswa. Secara harfiah pembinaan berarti pemeliharaan secara dinamis dan berkesinambungan. Didalam konteksnya dengan suatu kehidupan beragama, maka pengertian pembinaan menurut Rahmawati (2015) "adalah segala usaha yang dilakukan untuk menumbubkan kesadaran memelihara secara terus menerus terhadap tatanan nilai agama agar segala perilaku kehidupannya senantiasa di atas norma-norma yang ada dalam tatanan itu".
Pembinaan kehidupan beragama sangat penting bagi anak, sebagaimana dikatakan oleh Zakiah Darajat yang dikutip Rahmawati (2012) bahwa: "Pembinaan moral dan agama bagi generasi muda tidak dapat dipisabkan dari keyakinan beragama. Karena nilai-nilai moral yang tegas, pasti, dan tetap, tidak berubah karena keadaan, tempat, dan waktu atau nilai yang bersumber kepada agama. Oleh karena itu dalam pembinaan generasi muda, kebidupan moral dan agama harus sejalan dan mendapat perbatian yang serius".

Pelaksanaan kegiatan keagamaan di sekolah hendaknya memperhatikan pendekatan, strategi, metoda, dan teknik. Pendekatan merupakan cara pandang terhadap suatu obyek persoalan atau aktivitas, dimana pendekatan itu terdiri atas sejumlah startegi. Strategi merupakan upaya-upaya yang digunakan dalam suatu proses kegiatan dengan mempertimbangkan situasi dan kondisi, sumber belajar, kebutuhan dan karakteristik peserta didik yang dihadapi dalam rangka mencapai tujuan pembelajaran tertentu. Sehingga strategi terdiri atas sejumlah metoda. Metoda merupakan cara yang digunakan dalam suatu aktivitas yang lebih bersifat prosedural, berisi tahapan tertentu. Sedangkan teknik merupakan cara operasional untuk mengarahkan kegiatan mencapai tujuannya. Pendekatan dalam kegiatan keagamaan dapat dilakukan seperti halnya dalam pembelajaran. Ramayulis (2006:169-175) mengungkapkan pendekatan dimaksud terdiri atas: “( (a) pendekatan pengalaman, (b) pendekatan pembiasaan, (c) pendekatan emosional, (d) pendekatan rasional, (e) pendekatan fungsional, dan (f) pendekatan keteladanan, dan (g) pendekatan terpadu”.

Kegiatan keagamaan di sekolah hendaknya berorientasi kepada pembentukan afektif melalui pembentukan sikap mental peserta didik ke arah menumbuhkan kesadaran beragama. Beragama tidak hanya pada kawasan pemikiran saja, tetapi juga memasuki kawasan rasa. Karena itu, sentuhansentuhan emosi beragama perlu 
dikembangkan. Menurut Haidar Putra Dulay (2004:42-44) menyatakan bahwa: " $d i$ antara metoda pendidikan yang banyak kaitannya dengan sentuban emosi adalab: (a) Bimbingan Kehidupan Beragama, (b) Uswatun Hasanah (contoh teladan), (c) Malam Ibadah, (d) Pesantren Kilat, (e) Laboratorium Pendidikan Agama, dan (f) Iklim Religius". Sementara Ramayulis (2006:193-1980) mengungkapkan bahwa metoda dalam pendidikan Islam meliputi: "(a) ceramah, (b) tanya jawab, (c) diskusi, (d) pemberian tugas, (e) demonstrasi, (f) eksperimen, (g) kerja kelompok, (b) kisah, (i) amsal (perumpamaan), dan (j) targhib dan tarbib". Terkait dengan penggunaan metode dalam pembinaan agama Islam, Mastuhu yang dikutip Ahmad Munjin Nasih (2009: 33-35) menawarkan konsep pemikiran metode pendidikan Islam yang sifatnya lebih teknis, sebagai berikut: " menggunakan paradigma bolistic, penjelasan yang rasional, teknik pembelajaran partisipatif, dan lebih diorientasikan pada apa yang dikerjakan peserta didik". Sementara Qomar (2003:25) membagi metode pembelajaran agama Islam menjadi: "rasional, kritik, komparatif, dialogis, dan intuitif".

Prosedur yang ditempuh dalam Pembinaan keagamaan memuat rangkaian kegiatan yang harus dilakukan oleh Pembina dan yang dibina secara berurutan untuk mencapai tujuan pembinaan. Penentuan langkah pembinaan sangat penting artinya bagi penetapan materi yang bersifat prasyarat. Rumusan pernyataan dalam prosedur pembinaan minimal mengandung dua unsur ciri yang mencerminkan pengelolaan pengalaman belajar peserta pembinaan, yaitu kegiatan peserta pembinaan dan materi. Secara rinci prosedur yang ditempuh dalam proses pembinaan keagamaan meliputi:

Merencanakan pembinaan,

Melaksanakan pembinaan, dan (c) Menilai Kegiatan Pembinaan

Model pembinaan keagamaan berhubungan dengan model pembelajaran. Model pembelajaran pada umumnya adalah sebagaimana dikemukaan Joyce dan Weil
(Syaiful Sagala, 2005:176) yaitu empat kategori yang penting. Keempatnya adalah yakni model informasi, model personal, model interaksi dan model tingkah laku. Model pembinaan dapat diartikan sebagai "suatu rencana atau pola yang digunakan dalam menyusun kurikulum, mengatur materi dan memberi petunjuk kepada pembina dalam setting pembinaan". Penciptaan model-model pembinaan didasari pada asumsi bahwa hanya ada model pembinaan tertentu yang cocok untuk ditangani dengan model pembinaan tertentu. Jadi untuk pembinaan tertentu diperlukan model pembinaan tertentu pula. Banyak cara yang ditemukan dalam menentukan model pembinaan. Ada yang ditemukan melalui suatu penelitian khusus, kajian mendalam, pelatihan, maupun melalui suatu terapi. Akan tetapi pada dasarnya penemuan model pembinaan dilakukan melalui dua cara, yakni kajian teoritik dan kajian berdasarkan empiris. Sehingga akan ditemukan model pembinaan yang simple dan ada pula model pembinaan yang kompleks. Untuk itu, pendidik sebagai ujung tombak di dalam melaksanakan proses pembinaan, memiliki kewenangan untuk dapat menentukan model pembinaan yang bagaimana yang akan dikembangkan.

Penentuan model pembinaan pada dasarnya dapat ditentukan berdasarkan karakteristik materi dan relevansi materi dengan ketercapaian tujuan yang ingin dicapai. Sehubungan dengan hal tersebut, maka Bruce Joyce dan Marsha Weil membagi model mengajar itu kedalam empat rumpun yang memiliki orientasi dan cara belajar siswa yang berbeda. (1) Model Pemrosesan Informasi (Information Processing); Rumpun ini terdiri atas model mengajar yang menjelaskan bagaimana cara individu memberi respon yang datang dari lingkungan atau menekankan cara-cara dalam meningkatkan dorongan alamiah manusia untuk membentuk makna tentang dunia (sense of the world) dengan memperoleh dan mengolah data, merasakan masalahmasalah dan menghasilkan solusi-solusi nyang tepat, serta mengembangkan konsep 
dan bahasa untuk mentransfer solusi/data tersebut, atau dengan kata lain dengan cara mengorganisasikan data, memformulasikan masalah, membangun konsep dan rencana pemecahan masalah serta penggunaan simbol-simbol verbal dan non verbal. (2) Model Pribadi (Personal); Rumpun model personal terdiri atas model mengajar yang berorientasi kepada perkembangan diri individu. Siswa, dengan model mengajar ini diharapkan dapat melihat diri mereka sebagai pribadi yang berada dalam suatu kelompok dan cukup mempunyai kecakapan (capable). Dengan demikian ia dapat menghasilkan hubungan interpersonal yang cukup kaya. (3) Model Sosial (Social); Rumpun model mengajar Interaksi Sosial ini mengutamakan hubungan individu dengan masyarakat atau orang lain, dan memusatkan perhatiannya kepada proses dimana realita yang ada dipandang sebagai suatu negosiasi sosial (social negotiated). (4) Model Perilaku (Behavioral); Rumpun model Perilaku ini dibangun atas dasar teori yang umum, yaitu kerangka teori perilaku. Salah satu cirri dari rumpun model mengajar ini ialah adanya kecenderungan memecahkan tugas belajar kepada sejumlah perilaku yang kecil-kecil dan berurutan.

\section{PEMBAHASAN}

Terdapat 11 kegiatan yang telah dirancang yang masuk kategori kegiatan keagamaan IRMA Luqman SMA Negeri 10 Bandung, pada umumnya menggunakan pendekatan: pengalaman, pembiasaan, emosional, rasional, fungsional, dan keteladanan. Atau dengan kata lain pendekatan terpadu digunakan dalam melaksanakan berbagai kegiatan. Pendekatan terpadu seperti yang dikemukakan Ramayulis (2006:175) adalah “ pendekatan yang dilakukan dalam proses kegiatan dengan memadukan secara serentak beberapa pendekatan".

Materi kegiatan keagamaan yang ditemukan dalam seluruh aktivitas di lingkungan IRMA Luqman SMA Negeri 10
Bandung secara umum meliputi: aqidah, ibadah, muamalah, akhlak, al qur an, hadis, dan sejarah Islam. Namun demikian, dari 11 kegiatan tersebut, terdapat satu kegiatan yang menjadi dasar bagi kegiatan lainnya, yakni Pembinaan Pelajar Pemuda Islam (P3I). Kegiatan P3I merupakan kegiatan dakwah sekolah yang menjadi ciri khas kegiatan IRMA Luqman, dibagi menurut kelas dan semester. Materi P3I yang diberikan pada semester I sebanyak 11 tema, dan pada semester II sebanyak 6 tema.

Langkah-langkah yang dilakukan dalam setiap kegiatan, secara umum menempuh tiga tahapan, yakni adanya perencanaan, pelaksanaan, dan penilaian terhadap pelaksanaan kegiatan. Penentuan langkah pembinaan sangat penting artinya bagi penetapan materi yang bersifat prasyarat. Rumusan pernyataan dalam prosedur pembinaan minimal mengandung dua unsur ciri yang mencerminkan pengelolaan pengalaman belajar peserta pembinaan, yaitu kegiatan peserta pembinaan dan materi. Sedangkan metoda yang digunakan disesuaikan dengan jenis kegiatan. Secara umum metoda ceramah digunakan mendasari berbagai metoda lainnya yakni: metoda Tanya Jawab, resitasi, dan kerja kelompok.

Sebuah model kegiatan dibangun berdasarkan pendekatan, langkah-langkah, materi, dan metoda. Model pembinaan dapat diartikan sebagai "suatu rencana atau pola yang digunakan dalam menyusun kurikulum, mengatur materi dan memberi petunjuk kepada pembina dalam setting pembinaan". Penciptaan model-model pembinaan didasari pada asumsi bahwa hanya ada model pembinaan tertentu yang cocok untuk ditangani dengan model pembinaan tertentu. Jadi untuk pembinaan tertentu diperlukan model pembinaan tertentu pula. Banyak cara yang ditemukan dalam menentukan model pembinaan. Ada yang ditemukan melalui suatu penelitian khusus, kajian mendalam, pelatihan, maupun melalui suatu terapi. Akan tetapi pada dasarnya penemuan model 
pembinaan dilakukan melalui dua cara, yakni kajian teoritik dan kajian berdasarkan empiris. Sehingga akan ditemukan model pembinaan yang simple dan ada pula model pembinaan yang kompleks. Untuk itu, para pembina sebagai ujung tombak di dalam melaksanakan kegiatan keagamaan pada IRMA SMA Negeri 10 Bandung, memiliki kewenangan untuk dapat menggunakan model pembinaan yang yang akan digunakankan.

Merujuk pada berbagai aktivitas IRMA Luqman SMA Negeri 10 Bandung, secara umum tahapan yang harus dilakukan dimulai dengan pencerahan terlebih dahulu.
Oleh karenanya pemikiran Walter Dick dan Lou Carey (1985:4-5) yang dikutip Nan Rahminawati (2010:11) kiranya dapat dijadikan pedoman: "The model is based not only upon theory and research, but also a considerable amount of practical experience in its application. We acknowladge that in particular circumtances and with increased experience with a model, you may be ruquired to change the model. Also, we expect that more research and experiences will help amplify the procedures associated with each component of the model'. Gambar 1 di bawah ini menunjukkan tahapan pencerahan yang dilakukan.

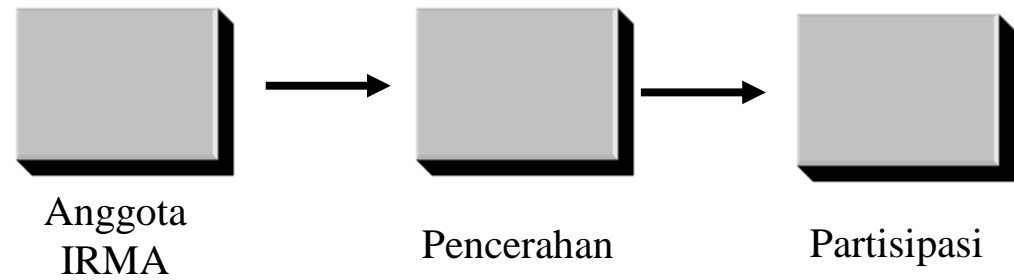

Gambar 1. Tahapan dalam Pencerahan (Sumber: Nan Rahminawati)

Walaupun berdasarkan pada empat rumpun model yang diungkap Bruce Joyce dan Marsha Weil yang telah diuraikan di atas, namun kiranya secara menyeluruh model yang dapat dikembangkan dapat menggunakan model Input, Proses, dan Output. Gambar di bawah ini menunjukkan Model Pengembangkan Kegiatan Keagamaan Pada Ikatan Remaja Masjid SMA Negeri 10 Bandung yang diusulkan.

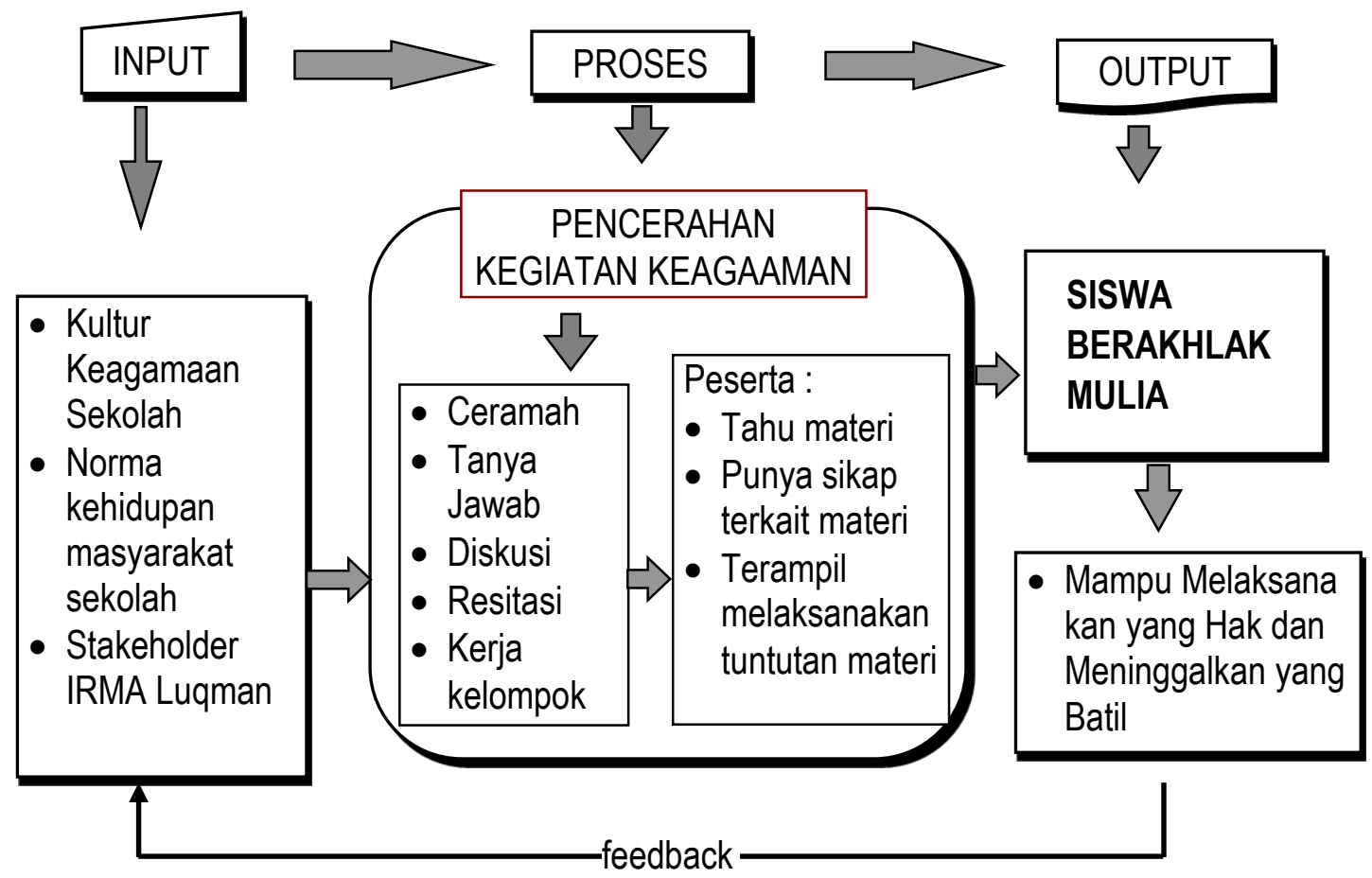


Gambar 2. Model Pengembangan Kegiatan Keagamaan pada IRMA Luqman SMA Negeri 10 Bandung (Sumber: Nan Rahminawati)

\section{KESIMPULAN}

Penlitian ini memperoleh kesimpulan bahwa: (1) Pendekatan yang digunakan dalam kegiatan keagamaan pada IRMA Luqman SMA Negeri 10 Bandung pada umumnya menggunakan pendekatan: pengalaman, pembiasaan, emosional, rasional, fungsional, dan keteladanan. Atau dengan kata lain pendekatan terpadu digunakan dalam melaksanakan berbagai kegiatan. (2) Materi kegiatan keagamaan yang ditemukan dalam seluruh aktivitas di lingkungan IRMA Luqman SMA Negeri 10 Bandung secara umum meliputi: aqidah, ibadah, muamalah, akhlak, al qur an, hadis, dan sejarah Islam. (3) Langkah-langkah yang dilakukan dalam setiap kegiatan, secara umum menempuh tiga tahapan, yakni adanya perencanaan, pelaksanaan, dan penilaian terhadap pelaksanaan kegiatan. (4) Metoda yang digunakan disesuaikan dengan jenis kegiatan. Secara umum metoda ceramah digunakan mendasari berbagai metoda lainnya. Dari 11 kegiatan yang dilakukan, maka metoda yang digunakan Tanya jawab, diskusi, kerja kelompok, dan resitasi. (5) Model yang dikembangkan pada 11 kegiatan dikelompokkan pada model processing informasi, social, dan behavioral. Selanjutnya, model pengembangan kegiatan kegamaan pada IRMA Luqman SMA Negeri 10 Bandung dapat menggunakan model Input, Proses, Output.

\section{DAFTAR PUSTAKA}

Abdullah. Irwan, dkk. (2008). Agama, Pendidikan Islam, dan Tanggung Jawab Sosial Pesantren. Pustaka Pelajar, Yogyakarta.

Arief, Armay. (2005). Reformulasi Pendidikan Islam. CRSD Press, Jakarta.

Ash-Sahawwaf, Muhammad Syarif. (2003). ABG Islami; Kiat-kiat Efektif
Mendidik Anak dan Remaja. Pustaka Hidayah, Bandung.

Dahlan, MD. (1990). Model-Model Mengajar: Beberapa Alternatif Interaksi Belajar-

Mengajar. CV Dipenogoro, Bandung.

Daulay, Haidar Putra. (2007) Pendidikan Islam dalam Sistem Pendidikan Nasional di Indonesia. Prenada Media, Jakarta.

Departemen Pendidikan Nasional Republik Indonesia. (2003). Undang-Undang Republike Indonesia Nomor 20 Tabun 2003 tentang Sistem Pendidikan Nasional. Jakarta

Haidar Putra Daulay. (2004). Pendidikan Islam dalam Sistem Pendidikan Nasional di Indonesia. Prenada Media, Jakarta.

Joyce, Bruce and Marsha Weil. (2011). Models of Teaching. Englewood Cliffs, New Jersey.

Lickona, Thomas. (2012). Educating for Character: How Our Schools Can Teach Respect and Responsibility. Alih bahasa: Juma Abdu Wamaungo, Bumi Aksara. Jakarta.

Lincoln,I.S dan Guba, E.G. (1985). Naturalistic Inquery. Sage Publishing Inc, London.

Majid, Abdul dan Dian Andayani. (2004). Pendidikan Agama Islam Berbasis Kompetensi: Konsep dan Implementasi Kurikulum 2004. PT Remaja Rodsakarya, Bandung.

Mulyasa, E.. (2012). Manajemen Pendidikan Karakter. Bumi Aksara, Jakarta.

Munjih Nasih, Ahmad dan Nur Kholidah, Lilik. (2009). Pendidikan Agama Islam: Metode dan Teknik Pembelajaran. PT.Refika Aditama, Bandung.

Nasution, S. (1988). Metode Penelitian Naturalistik Kualitatif. Tersito, Bandung.

Rahminawati, Nan. (2010). Model Optimalisasi Pemberdayaan Perempuan Muslimab: Suatu Penyadaran ke Arah 
Eksistensinya. Fakultas Tarbiyah, Univrsitas Islam Bandung. (2015). Model-Model Mengajar. Fakultas Tarbiyah, Universitas Islam Bandung.

Rahmawati. (2012). Blogspot: Pembinaan Keagamaan di Sekolah. 14/9/2012.

Ramayulis. (2006). Ilmu Pendidikan Islam. Kalam Mulia, Jakarta.

RC, Bogdan dan Biklen SK. (1982). Quialitative Research for Education. Allyn and Bacon Inc, Boston. 